\title{
Multiple Meanings of the Ending of Seize the Day
}

\author{
Xiaoxia Zhang \\ School of Foreign Languages \\ Shaanxi Normal University \\ Xi'an, China
}

\begin{abstract}
The ending of Seize the Day, one of the representative works of American contemporary famous writer Saul Bellow, has multiple meanings. Firstly, in the first part of his life, Wilhelm is constrained by his "pretender soul". At the end of the novel, in the Jewish chapel, Wilhelm begins to realize the "ultimate need of his heart" is to seek the "real soul". Secondly, in the Jewish chapel, Wilhelm realizes his Jewish identity once again. The awareness of suffering comes to the surface of his mind again. Wilhelm's spirit is redeemed. Thirdly, in spite of the pitiful relationship between people, Wilhelm identifies with and adheres to the commandment of loving one's neighbors in Jewish ethics.
\end{abstract}

Keywords-Saul Bellow; Seize the Day; "real soul"; redemption; loving neighbors

\section{INTRODUCTION}

Seize the Day, one of the representative works of the renowned contemporary American writers Saul Bellow, is welcomed by the readers because of its intricate structure and profound theme. Different critics hold different ideas about this novella. Some people think that Wilhelm's tears shed at a stranger's funeral are pathetic, signifying weak and incompetent Wilhelm's lament over his pathetic situations. Some argue that the noble and joyous tears indicate Wilhelm's new life, symbolizing his spiritual redemption (Liu Xiying 2010:114) Some people view that Wilhelm's tears convey "the sympathy for the general destiny of humans and condolences over the spiritual death of the western civilization" (Xue Xiaohui 2008:44) The author of this article views that the ending of this novella has multiple meanings and can be understood from the following perspectives: Firstly, Wilhelm begins to get rid of his "pretender soul" and seek "the real soul"; secondly, Wilhelm tries to regain his Jewish identity and the awareness of suffering reemerges; thirdly, Wilhelm utters lament over people-to-people relationship but adheres to the commandment of loving compatriots of Jewish ethics.

The novella tells about Wilhelm's life experiences and the spiritual crisis he was undergoing by depicting his one day's activities. Middle-aged Wilhelm moves to Gloriana hotel where his father lived after he has retired. Wilhelm quits his job since he was at odds with his former boss. Estranged with his wife Margaret, Wilhelm tries to divorce but is refused by his wife. He has to support his wife and two sons. Cornerd by life, he gives his seven hundred dollars, the only left money, to Tamkin to do speculation. The business fails and Tamkin runs away. In the process of seeking
Tamkin, Wilhelm is carried to a chapel. In front of a stranger's dead body, Wilhelm sobs hard.

\section{WILHELM'S TENDENCY TO GET RID OF THE "PRETENDER SOUL"}

Doctor Tamkin in the novella is a complicated figure. On the one hand, he always brags and utters some unrealistic remarks. On the other hand, there is something in some of his theories. For example, his theory about "the pretender soul and the real soul" can be viewed as the manifestation of Saul Bellow's consistent thought. There is a saying in Jewish culture, which goes "There is both a good angel and a bad angel". Saul Bellow himself used "sub angelic" to describe mankind. "Sub angelic" means that in humans there are angelic traits but humans are always inferior to angels. Our country's famous scholar Nie Zhenzhao illustrates Sphinxes factor in his Introduction to Ethical Literary Criticisms. Sphinxes has both "good" and "evil" factors. "Good angels" "bad angels" "good factors" "evil factors" indicate that in human nature there are positive side and negative side. The positive side corresponds to "the real soul" while the pretentious side corresponds to "the pretender soul"

"The pretender soul" comes into being because people shun their true hearts and pursue fame and benefits under the influence of the secular society. In Wilhelm's first part of life he is reined by his "pretender soul". He changes his name and goes to Hollywood against his family members' will in the hope of becoming a movie star. As a result he does not fulfill that dream and he does not graduate from university. Before marrying Margaret he realized he did not love this woman but he marries her at last. He is fully aware that Tamkin is a swindler but he still gives his money to him to do business. All these show that Wilhelm ignores the pursuit for the truth and the beauty for the sake of the external fame and benefits. He is overwhelmed by "the pretender soul" which stands for the worldly wants.

Reined by "the pretender soul", Wilhelm gains nothing and is deprived totally by life. Nevertheless, Wilhelm begins to contemplate "the real and the pretender soul" just when he is plunged to the bottom of life. "The pretender soul" leads his life to a blind alley, but "the real soul" is "the heart's ultimate need". Wilhelm has this initiation in front of the stranger's dead body in the chapel. The Jewish man is empty-handed, just like all others who left the world. This reminds Wilhelm of his past, his "pretender soul". Recalling all these, his tears pour down. The tears flush away the pretender soul in his body. Maybe some people will never 
get rid of the pretender soul, but Wilhelm begins to realize he should pursue the real soul since "He heard it and sunk deeper...toward the consummation of his heart's ultimate need"( Bellow, 114). He chooses to return to the real soul which will lead him to his true needs. The needs are to love compatriots, love mankind and connecting one's own life with the lives around. Only by doing this can a person lead a meaningful and happy life.

\section{HAVING SPIRITUAL REDEMPTION BY REGAINING JEWISH IDENTITY}

Though Saul bellow did not claim to be a Jewish writer, as a son of devout parents, it is impossible for him not to be deeply influenced by Jewish ethics. The pattern of "betrayalrepentance-redemption" remerges in his works. At the end of Seize the Day, Wilhelm is carried to a chapel by a crowd. The tears he sheds in front of a strange Jewish man's body show he finally returns to his Jewish identity and fulfills spiritual redemption by suffering.

Wilhelm's initial name is Wilky. Tommy is the new name he gives himself in California. He tries to change his Jewish identity by throwing away the name Wilky. But the result is "He had never, however, succeeded in feeling like Tommy, and in his soul had always remained Wilky"( Bellow 21). Wilky is a typical Jewish name while Tommy an American one. As a Jewish immigrant in America, Wilhelm is eager to integrate into American culture and gets away from his ancestors' Jewish identity. "Wilhelm had always had a great longing to be Tommy."( Bellow 21). That means he yearns to be a member of American mainstream culture. He insists going to California and changes his name. He never goes to synagogue and never attends religious rituals. When old Rappaport asks if Wilhelm reseved a sear for Yom Kippur, he says no. Yom Kippur is one of the most important holidays in Jewish culture. On that day, people repent for the sins they have committed over the past year, forgiving others and asking for others' forgiveness. Jewish Pappaport never misses that day while Wilhelm realizes he should have reserved a seat and pray for his mother.

Wilhelm, who has been trying to get rid of his Jewish identity, is confronted with failure after failure. He comes to realize he can never become Tommy. Though Tamkin warns him that "Don't marry suffering", Wilhelm still feels that "if they quit suffering they're afraid they'll have nothing"( Bellow 94). Repentance has become the collective unconsciousness of the Jewish people. The mode of the whole old testament is "betrayal-repentance-redemption". God first chose the Israelis and made the covenant with them. The covenant required both sides to shoulder respective duties and obligations. The Israelis were supposed to be submissive to God while God promised to protect the Israelis and provide land for them and make them multiply. In the old Testment the Israelis broke their promises over and over again. Especially when they had easy lives. As a consequence they were severely punished, leaving their motherland and suffering a lot. In severe tribulations they began to contemplate and repent. They realized it was their betrayal of God that led to their sufferings. Then they repented again and again, asking for God's forgiveness. In the end benevolent God showed mercy and forgave them and redeemed the Israelis. Gradually the Israelis develop the awareness of suffering and repentance, thinking that the way to please God and redeem one's soul is to suffer for others. Though Wilhelm is battered again and again and feels infuriated over becoming others' victim, when he sees the Jewish man's body, his awareness of suffering emerges. The suffering is closely related to redemption. For that reason his tears are "great and happy". It is "great" because suffering for others is great; it is "happy" because he achieves spiritual redemption through suffering.

\section{LAMENT OVER PEOPLE-TO-PEOPLE RELATIONSHIP WHILE CHOOSING TO ADHERE TO THE COMMANDMENT OF LOVING COMPATRIOTS}

The father-son relationship constitutes a major part of the novella. Some people argue that the whole novella is about the relationship between a father and a son. In Seize the Day the father-son relationship remains tense all along. Many reasons account for that. Firstly in the father's eyes, Wilhelm is a slob and a disappointing son without much responsibility. Each of their conversations is unpleasant. The father thinks the son should bear full responsibility for his misfortune and should not count on the father for help. To Wilhelm, his father is able to help him but "when I suffer you aren't even sorry. That's because you have no affection for me" ( Bellow 50). Secondly, the conflict between Wilhelm and Adler is the result of the conflict between Jewish culture and American culture. Doctor Adler, who has been assimilated into American society, is deeply influenced by individualism. He thinks a person should be responsible for their own actions. If he fails, he should not expect help from anybody else, including his family members. When Wilhelm turns to him for help, he utters "I want nobody on my back. Get off. And I give you the same advice, Wilky, carry nobody on your back." (Bellow 51) He owes his success to his personal struggles. So he thinks that he is entitled to enjoy his remaining years in comfort and will not give a helping hand to his children. Though the father is pathetic and merciless, Wilhelm shows love and respect for his parents all along. "Children must be filial to their parents and take care of them when the parents are old or sick." (Cohon 2009: 135) Refused by his father when he seeks help, he thinks bitterly" If he were poor, I would care for him and show it. The way I could care, too, if I only had a chance. He'd see how much love and respect I had in me." ( Bellow 53) The fact is that he does not have any chance to express his love for his father. From the worldly perspective, he is a son who is in bad need of financial help with Jewish ethics of family concept. On the other hand, his father is successful financially but is deeply influenced by individualism. Their communications are bound to be fraught with obstacles. The disadvantageous son is sure to suffer disappointments and agony.

Rejected by his father, Wilhelm tells himself to understand his father's acts and ponder "He is as much father as I am son-old or not"( Bellow 40). In spite of that, Wilhelm laments over this unconcerned father-son relationship. Once he cries to his father "The money makes the difference"( Bellow 51). He thinks that if he were rich, his 
father's attitude towards him would be different and he did not have to taste the bitterness of being rejected or even hated. He laments that the feelings among people become appendages. He laments the general feelings advocated in Jewish culture become an illusion.

Though Wilhelm's feelings are hurt by his father, his wife and Tamkin, he still adheres to the deep feelings towards the "larger body". The "larger body" refers to neighbors, compatriots and the whole mankind. Jewish culture emphasizes that individuals and compatriots are integral. God creats individuals as well as their neighbors, whom are connected through God. A person shows respect for himself through his respect for others. A person's contempt against others indicates his blasphemy since others also were created in the image of God. There is a saying in Talmud which goes "Love God by loving humans who were created by God." "Serving your neighbor is serving God." (Baeck 2002: 169) A person who only cares about his own interests can not please God since a person can meet God on the way to serve his compatriots. Each person is obliged to help and love his compatriots whether the compatriot is beautiful or ugly, rich or poor. As long as he has the image of a human, he deserves the help.( Baeck 2002:170) Wilhelm has such love for his compatriots and mankind. Once in the passage under the Times Square, such feelings surge. He feels "he loved them. One and all, he passionately loved them. They were his brothers and his sisters" (Bellow 81).

At the end of the novella, in front of the stranger's dead body, Wilhelm's feelings surge like tides. "Another man" in the coffin reminds him of himself and his father. Meanwhile the man in the coffin is one of the "larger body", his brother, mankind. Weeping in front of that stranger, his tears are not just for that person, but also for himself. After wailing his own misfortunes and others' attitudes towards him, Wilhelm forgives himself as well as others. In the tears rolling down, he transcends self-pity and enters into philanthropy.

To sum up, the ending of Seize the Day has multiple meanings. After experiencing middle age crisis, Wilhelm begins to get rid of the "pretender soul" and seek the "real soul". He finds people can only be redeemed after undergoing suffering. After being rejected by his father, his wife and his spiritual adviser, Wilhelm chooses to love others. Because of this, in the great and happy tears, Wilhelm gains new life and embarks on the road to real happiness.

\section{REFERENCES}

[1] Baeck, Leo. The Essence of Judaism. Trans. Fu Yongjun\&Yu Jian. Shandong University Press, 2002.

[2] Bellow, Saul. Seize the Day. New York: Penguin Books, 2003.

[3] Cohon, Samuel S. Judaism: A Way of Life. Trans. Xu Xin etc. Sichuan People's Press, 2009.

[4] Liu Xiying. The Suffering and Redemption in Seize the Day. World Literature Review, 2010(2).

[5] Nie Zhenzhao. An Introduction to Ethical Literary Criticism. Beijing: Peking University press, 2014

[6] Xue Xiaohui. Lament Over the Spiritual Death of Western Civilization: Analysis of the Theme of Saul Bellow's Seize the Day. Xi'an International Studies University Journal, 2008(1). 